\title{
CRONÍSTICA AFONSINA MODELADA EM PORTUGUÊS: UM CASO DE RECEPÇÃO ACTIVA*
}

\author{
ISABEL DE BARROS DIAS
}

Universidade Aberta, Lisboa

RESUMEN: Este artículo estudia el modo en el que las crónicas realizadas en el occidente de la Península Ibérica (la "Traducción Gallega» y la primera y segunda redacción de la portuguesa "Crónica de 1344») manipularon algunos textos de la "Estoria de Espanna" alfonsina y post-alfonsina, que usaron como fuente. La comparación entre las diferentes crónicas evidencia la extensión y la profundidad del trabajo llevado a cabo, ya sea a nivel de extensos bloques textuales o de detalle. Aquí se verifica que estas crónicas mantienen la referencia autoral de prestigio (Afonso X, el rey Sabio) $y$, simultáneamente, adecuan los contenidos vehiculados a sus intereses específicos. De este modo, frente a las narraciones elaboradas en el centro de la Península, las crónicas del extremo occidental van a vehicular puntos de vista alternativos sobre algunos pasajes de la bistoria peninsular. Por un lado, defienden el buen nombre de sus poblaciones y de sus reyes. Por otro lado, y especialmente la segunda redacción de la "Crónica de 1344», evidencian la voluntad de justificar y garantizar un lugar en la historia para el reino más reciente de la Península: Portugal.

Palabras Clave: Historiografia. Traducción Gallega. Crónica de 1344. Estrategias retóricas. Recepción.

* São aqui usadas as seguintes siglas:

PCG $=$ Primera Crónica General de España

Cr20R = Crónica de Veinte Reyes

Trad.Gall = Traducción Gallega de la Crónica General y de la Crónica de Castilla

$1344 \mathrm{a}=$ Crónica Geral de Espanha de 1344 (1ª redacção)

$1344 \mathrm{~b}=$ Crónica Geral de Espanha de 1344 (2 redacção)

Este artigo retoma assuntos já apresentados em artigos anteriores (que serão indicados, sempre que tal se justifique) e, particularmente, em DiAs, I. B., Metamorfoses de Babel. A historiografia ibérica (sécs. XIII-XIV): Construçẽes e estratégias textuais, Lisboa, Fundação Calouste Gulbenkian / Fundação para a Ciência e Tecnologia - Ministério da Ciência e do Ensino Superior, 2003. 
ABSTRACT: This article studies how the chronicles produced in the western part of the Iberian Peninsula (the "Traduccion Gallega» and the first and second versions of the Portuguese "Crónica de 1344») manipulated some texts of the Alphonsine and Postalphonsine "Estoria de Espanna», used by them as source. The comparison of the different chronicles reveals the extension and the depth of the work done, both at the level of large textual blocks, and of detail. These chronicles keep the prestigious authorial reference to Alphonso $X$, the Wise king and, at the same time, adapt the contents to their own particular interests. Thanks to these procedures, opposed to the chronicles produced in the centre of the Iberian Peninsula, the chronicles of the extreme west will convey alternative points of view on some passages of the peninsular history. On the one hand they defend the good name of its populations and of its kings. On the other hand, in particular the second version of the "Crónica de 1344" makes evident efforts to justify and to guarantee a place in history for the most recent kingdom of the Peninsula: Portugal.

KEY WORDS: Historiography. Traducción Gallega. Crónica de 1344. Rhetorical strategies. Reception.

A Estoria de Espanna ${ }^{1}$ afonsina foi uma das obras de maior sucesso na Península Ibérica, no período medieval ${ }^{2}$. Tem sido, também, uma das obras que mais trabalho deu e continua a dar à crítica textual, no quadro da delimitação das suas partes e da respectiva datação, ao que acresce ainda a questão da definição das suas diversas versões e variantes ${ }^{3}$.

1 Os textos aqui usados para as duas principais versões afonsinas da Estoria de Espanna foram os seguintes: para a «versão primitiva» (cerca 1270) foi usado o testemunho parcial da "versão régia», que integra o texto editado por MENÉNDez PIDAL, R.: Primera Crónica General de España, Madrid, Gredos, 1977, onde constitui o trecho inicial (até ao cap. 616). O restante texto desta edição terá sido elaborado em épocas distintas que, quando pertinente, serão referidas. Como representante da «versão crítica» (cerca 1282-84), foi usada a transcrição de um exemplar da denominada Crónica de Vinte Reis: Ruiz Asencio, J. M. e Herrero Jiménez, M. (transcr.): Crónica de Veinte Reyes, Burgos, Ayuntamiento de Burgos, 1991, ramo que só representa parcialmente a "versão crítica» uma vez que as crónicas conhecidas como Cr20R só se iniciam no período da Reconquista.

2 Bernard Guenée refere a Estoria de Espanna como um exemplo de texto de circulação restrita à Península Ibérica, onde a sua influência foi, no entanto, marcante (inclusivamente porque o sucesso de uma obra se mede não só pela divulgação da mesma, como também por outros vestígios da sua leitura que se revelam pela existência de interpolações, adições, continuações, empréstimos, traduções, abreviações, adaptações...): GuENÉE, B., Histoire et culture historique dans l'Occident médiéval, Paris, Aubier-Montaigne, 1980, pp. 255 e 270-71.

3 Sobre as versões afonsinas e suas combinações e reescritas, ver Catalán, D.: De Alfonso X al conde de Barcelos, Madrid, Gredos, 1962 e, mais recentemente, idem, De la silva textual al taller bistoriográfico alfonsi. Códices, crónicas, versiones y cuadernos de trabajo, Madrid, Fundación Ramón Menéndez Pidal / Universidad Autónoma de Madrid, 1997 e IDEM, La Estoria de España de Alfonso X. Creación y evolución, Madrid, Fundación Ramón Menéndez Pidal / Universidad Autónoma de Madrid, 1992. Ver ainda FERnÁndeZ-ORdóñez, I., Versión Crítica de la Estoria de España, Madrid, Fundación Ramón Menéndez Pidal / Universidad Autónoma de Madrid, 1993, bem como a útil síntese: IDEM, «La transmisión textual de la «Estoria de España» y de las principales «Crónicas» de 
Um pouco mais circunscrito, no tempo e no espaço, está o ramo mais ocidental desta ampla família textual. As traduções para o galego e, posteriormente, para o português, da Estoria de Espanna configuram-se num universo relativamente pouco extenso de manuscritos, distribuídos por três blocos: a Traducción Gallega ${ }^{4}$ e a primeira e segunda versões da Crónica de $1344^{5}$.

Estes testemunhos, além de manterem múltiplas características próprias da família textual de onde derivam, caracterizam-se por introduzir alguns desvios significativos ao modelo cronístico cultivado no centro da Península Ibérica. Uma boa parte destas alterações tem implicações ideológicas. Desde o texto da Traducción Gallega, até à segunda redacção da Crónica de 1344, nota-se um processo gradual que se afirma, não tanto contra os reinos de Castela e Leão mas, sobretudo, a favor das regiões mais ocidentais. Assim, temos, por um lado, a defesa, do bom nome das populações e dos seus soberanos e, numa segunda fase, em crescendo, na primeira e segunda redacções da Crónica de 1344, a vontade de reservar um lugar na história para o reino mais recente da Península ${ }^{6}$. Sendo o espaço físico, geográfico de Portugal já uma realidade, era necessário conquistar também um lugar na memória e no imaginário. É esse o «combate ideológico»que o ramo português da historiografia afonsina trava, e do qual serão seguidamente apontadas algumas características.

A Traducción Gallega inicia-se com o reinado de Ramiro de Leão. Começa por seguir uma versão idêntica à do texto editado como Primera Crónica General que, nesse momento, já representa a «versão retoricamente amplificada» ${ }^{7}$, se-

ellas derivadas», Alfonso X el Sabio y las Crónicas de España, Valladolid: Fundación Santander Central Hispano / Centro para la Edición de los Clásicos Españoles, 2000, pp. 219-260.

4 O texto usado aqui usado foi o seguinte: LorEnzo, R. (ed.), La Traduccion Gallega de la Crónica General y de la Crónica de Castilla, Orense, Instituto de Estudios Orensanos «Padre Feijoo», 1975.

5 A primeira redacção desta crónica, redigida em 1344, em português, perdeu-se. Só resta uma tradução em castelhano da qual o melhor exemplar é o ms. 2656 da Biblioteca Universitária de Salamanca, aqui considerado, bem como a seguinte edição parcial: CATALÁN, D. e ANDRÉs, M. S. (eds.), I Edición Crítica del Texto Español de la Crónica de 1344 que ordenó el Conde de Barcelos don Pedro Alfonso, Madrid, Gredos, 1970. A minha numeração dos capítulos do ms. 2656 da Biblioteca Universitária de Salamanca segue a numeração existente na edição parcial. Para a segunda redaç̧ão, é usado o texto editado por CINTRA, L. F. L. (ed.), Crónica Geral de Espanha de 1344, Lisboa, IN-CM, 1951-1990 (4 volumes).

6 Refira-se também a existência de uma historiografia portuguesa anterior já marcada por uma forte identidade e que contrasta com as teses defendidas pela corrente historiográfica asturiana. Sobre esta questão ver DAVID, P (ed.), «Annales Portugalenses Veteres», Études historiques sur la Galice et le Portugal du VIe au XIIe siècle, Lisboa / Paris, Portugália / Les belles lettres, 1947, pp. 257-340. Cabe ainda salientar que os textos portugueses não foram os únicos que, na Península, se terão apropriado do fundo historiográfico afonsino a fim de o manipular em proveito próprio. O mesmo se verifica, por exemplo, com a Crónica d'Espayña de García de Eugui que, na última parte do séc. XIV, usa amplamente os materiais afonsinos como fonte de uma narrativa onde se procura valorizar o estatuto peninsular de Navarra, conforme é salientado no estudo que antecede a edição do texto: WARD, A. (ed.), Crónica d'Espayña de García de Eugui, Pamplona, Gobierno de Navarra, 1999, pp. 102-104.

7 O primeiro capítulo da Trad. Gall editada corresponde ao cap. 628 da PCG, posterior, pois, ao fim do que seria o ms E1(orig) que terminaria no cap. 616 da PCG. 
guindo com a cópia da denominada Crónica de Castilla. Apesar de não inovar muito, relativamente aos textos que traduz, também não deixa de introduzir algumas alterações.

A primeira redacção da Crónica de 1344, por seu turno, distingue-se por ter toda uma primeira parte de raiz não afonsina, sendo o passado mais remoto aí recuperado graças ao recurso a outras fontes com as quais foram elaboradas uma série de listagens genealógicas, relativamente pouco desenvolvidas ${ }^{8}$. A versão afonsina da história mais antiga só é recuperada na segunda redacção da Crónica de 1344. Este último texto apresenta-se, assim, mais uniforme, uma vez que já não se verifica a mudança brusca de tom que a primeira redacção evidenciava ao saltar da organização analística para um discurso mais descritivo e detalhado.

No que se refere a alterações ideologicamente mais significativas relativamente aos textos afonsinos e pós-afonsinos, verifica-se, entre as duas redaç̧ões da crónica portuguesa, um processo de construção e de sedimentação de uma identidade própria. O zénite desta evolução ocorre na segunda redacção da Crónica de 1344 que, como muito indica, terá tido lugar nos anos 80 do século $\mathrm{XIV}^{9}$, momento de crise económica e política, quando a primeira dinastia via aproximar-se o seu fim e em que o perigo de uma invasão castelhana tomava os contornos bem definidos de um perigo real e concreto. Com efeito, num momento destes, não seria muito adequado retomar um texto que fizesse a apologia de um Império Ibérico e/ou da supremacia de Castela, nesses mesmos termos. Um pequeno reino que não tinha cessado de lutar para aumentar o seu território (mormente a sul, contra os muçulmanos) e para manter a sua independência relativamente a vizinhos cristãos, consideravelmente mais poderosos (Leão ou Castela-Leão, consoante os períodos), teria forçosamente que reflectir, também ao nível da sua produção textual, uma das questões fundamentais para a Península Ibérica: a afirmação da existência (e do respectivo direito à existência) dos diversos reinos autónomos, em oposição a correntes que defendiam a união sob um Império.

8 Salvaguarde-se que, de acordo com os estudos levados a cabo, nomeadamente por Catalán, D.: 1992 (cap. VIII: «La expansión al occidente de la Península Ibérica del modelo historiográfico Estoria de España - nuevas precisiones», pp. 185-196) e 1997, o texto que terá servido de base à segunda parte do trabalho historiográfico de D. Pedro Afonso, conde de Barcelos, seria um ms. Hoje perdido, presumivelmente também o mesmo que esteve na base do ms. A1 (em Galego) que, no entanto, terá feito uma cópia mais descuidada (CATALÁN, D.: 1997, pp. 292-93). Assim, o texto galego aqui utilizado não é a fonte directa da Crónica de 1344, papel que terá sido desempenhado pelo seu arquétipo. Depreende-se, pela ausência dos trechos relativos à história mais antiga, na TradGall, e pelos acrescentos levados a cabo na 1344 a que este ms. Estaria também truncado, no que respeita aos períodos mais remotos. Sobre as fontes da primeira redacção da Crónica de 1344, veja-se o estudo introdutório à sua edição parcial por CATALÁn e ANDRÉs. Ver ainda MAtToso, J.: «Sur les sources du comte de Barcelos», em GeNET, J.-Ph.: L'historiographie médiévale en Europe, Paris, éditions du S.N.R.S., 1991, pp. 111-116.

9 A questão da datação da segunda redacção da Crónica de 1344 é discutida em DiAs (2003), I parte, ponto 4 . 
A Crónica de 1344, nas suas duas redacções, vem, não só assumir a defesa de Portugal e dos Portugueses, nem sempre presente nos textos anteriores ${ }^{10}$, mas ainda reflectir a efectiva ordenação territorial da Península, marcada pela partição, no que contraria a teia de alusões imperiais e a apologia da união ibérica, veiculada pelos relatos afonsinos ${ }^{11}$.

Os processos textuais / retóricos usados na redacção historiográfica, com vista à prossecução destas linhas, são as ferramentas habituais da dispositio, já anteriormente postas em prática no scriptorium de Afonso X, quer para acentuar os momentos considerados mais relevantes (graças a inserções e amplificações), quer, pelo contrário, para silenciar os momentos menos convenientes (por meio de supressões e de resumos). No entanto, o seu uso é aqui feito de acordo com ideais e finalidades distintos que vão minar a construção textual que o «Modelo» apresentava.

Estas manipulações textuais são visíveis, quer ao nível «macro», relativo a acções efectuadas sobre grandes blocos textuais, quer ao nível «micro», graças a pequenas alterações de pormenor que, por vezes, implicam grandes ou, pelo menos, consideráveis modificações de sentido. De seguida serão passadas em revista passagens ilustrativas destes dois tipos de recomposição textual. O seu cotejo com o veiculado, sobretudo, pela historiografia oriunda do scriptorium afonsino e daí decorrente revela-se bastante esclarecedor no que toca ao teor e ao alcance ideológico das intervenções efectuadas.

\section{INTERVENÇÕES AO NÍVEL DE GRANDES BLOCOS TEXTUAIS}

As adições e supressões de grandes blocos textuais são intervenções que saltam à vista de quem compara as crónicas afonsinas e pós afonsinas. A seguir são apontadas algumas das mais notórias e significativas no que se refere ao grupo de crónicas produzidas no ocidente peninsular, no âmbito do quadro ideológico acima esboçado. Estes exemplos são reveladores, precisamente, do modo como estas crónicas, com particular destaque para a segunda redacção da Crónica de 1344, se apropriaram e desviaram ideologicamente os relatos afonsi-

10 Note-se que o texto português manuseou variantes com reescritas que dificilmente seriam do agrado de um cronista português. Saliente-se a este respeito a constatação de FERNÁnDEZORDÓÑEZ, I.: «Variación en el modelo historiográfico alfonsí en el siglo XIII. Las versiones de la Estoria de España», em MARTIN, G.: La historia alfonsí: el modelo y sus destinos (siglos XIII-XV), Madrid, Casa de Velázquez, 2000, pp. $41-74$ (pp. 56-58) segundo a qual a «versão crítica» parece opor-se à independência portuguesa.

11 A questão da defesa de uma monarquia absoluta e do domínio universal (na falta do qual se faz o elogio dos reinos fortes e unidos em detrimento dos fracos e fragmentados) é apontada por FERNÁNDEZ-ORDÓÑEZ, I.: «Evolución del pensamiento alfonsí y transformación de las obras jurídicas e históricas del rey sabio», Cabiers de Linguistique Hispanique Médiévale, 23 (2000), pp. 26383 (pp. 274-78) como uma das características que transparecem tanto na obra historiográfica como na legal deste soberano. 
nos e pós-afonsinos de que se serviram. Para tal, foram usados, sobretudo, os procedimentos básicos de composição textual salientados pelas Artes Poéticas medievais: a abbreviatio e a amplificatio. $\mathrm{Na}$ verdade, o que se escolhe omitir, aquando da construção de um texto, mormente de uma crónica que é «O»lugar da preservação da memória do passado, é tão significativo como o que se escolhe integrar. Com efeito, se um cronista revela o que pretende exaltar com os relatos que amplifica, o que abrevia ou omite revela precisamente o que lhe convém esconder ou desvalorizar.

\section{a) A abbreviatio da narrativa relativa à História Antiga}

No que toca ao período da História Antiga, não é possível usar nem a Traducción Gallega, nem a primeira redacção da Crónica de 1344 enquanto termo de comparação, no que toca à transformação dos materiais afonsinos. A primeira porque só tem início no período da Reconquista, a segunda porque, para este momento, se baseia em fontes não afonsinas.

A segunda redacção da Crónica de 1344 já teve acesso à tradição afonsina, mas procede a uma abreviação flagrante da história desse período ${ }^{12}$. $\mathrm{O}$ alcance ideológico deste procedimento torna-se claro quando se constata que a fonte afonsina é truncada sistematicamente de modo a elidir múltiplas alusões imperiais. A desculpa apresentada refere o seguinte:

E, por que esta estoria dos que conquistaron as Spanhas ataa os Godos, fala de muytos que en ella veheron a conquistar, he forçado, por a hordenança da storya hir dereita, que, daqueles principes que en ella veheron e fezeron grandes feitos, que nos os metamos na estoria algu . as vezes, tomando hu . as cousas pequenas que fazem hordenãça na scriptura, ainda que non tangam muyto aos feitos d'Espanha, e leixando algu . us outros grandes feitos que elles fezeron que non pertençe. a esta estoria. (1344b: II, 76).

No entanto, a crónica portuguesa refere acontecimentos que tiveram lugar fora do território ibérico ${ }^{13}$, enquanto que diversas alusões à Hispania e aos imperadores de origem ibérica são esquecidas ${ }^{14}$. Este aparente paradoxo só se en-

12 O expurgar de alusões imperiais na História Antiga, pela segunda redacção da Crónica de 1344, é estudado, com maior detalhe, em DIAS, I. B., “"Translatio Auctoritatis”» em FrEIXAS, M., IrIso, S. e Fernández, L.: Actas del VIII Congreso Internacional de la Asociación Hispánica de Literatura Medieval, Santander, Consejería de Cultura del Gobierno de Cantabria, Año Jubilar Lebaniego y Asociación Hispánica de Literatura Medieval, 2000, pp. 639-649.

13 Caso da enumeração das diversas batalhas travadas entre Aníbal e os Romanos (1344b: II, 84-86).

14 Nomeadamente Galba, que é eleito Imperador (em oposição a Nero) em Espanha (PCG: cap. 178). Os bons Imperadores Nerva e Trajano (PCG: caps. 190-91) eram naturais da Hispania, assim como o «sábio e estudioso» Adriano (PCG: caps. 196, 198). 
tende se se tiver em consideração que é graças a supressões deste tipo que a crónica portuguesa pode desconstruir (por omissão) a argumentação e as diversas insinuação imperiais do discurso afonsino, que justifica do seguinte modo a inserção da história do Império Romano numa história de Espanha: «Mas por que en los fechos de los romanos tanne mucho de los de Espanna, por esso non podemos escusar que no fablemos dellos» (PCG: I, 84b).

No período da história Antiga também se encontra um exemplo de desvio de sentido de uma narrativa, por amplificação: trata-se do trecho que relata o périplo de Hércules e a sua actuação na Península Ibérica. Quando se coteja a «versão régia» afonsina com a segunda redacção da Crónica de 1344, verifica-se que, enquanto a primeira apresenta Hércules como o primeiro unificador da Península, a segunda dramatiza e dilata os traços mais romanescos do relato. Neste caso, a amplificação da narrativa é feita de modo a valorizar umas características em detrimento de outras, desviando assim o sentido dominante da história. Deste modo, a acentuação de uma imagem de Hércules como um exemplo de cavaleiro valoroso, de um cavaleiro errante em busca de aventuras «avant la lettre», vai implicar a diluição da sua dimensão política de primeiro unificador do teritório peninsular, o que constituiria, certamente, um exemplo muito mais interessante para os ideais políticos do rei Sábio ${ }^{15}$.

\section{b) A actualização e amplificação das histórias dos reinos mais periféricos}

$\mathrm{Na}$ narrativa do período da Reconquista, voltamos a encontrar situações onde a amplificação e o desenvolvimento de determinados pontos da história vão implicar a alteração do equilibrio relativo das partes que a compõem. Apesar do relato dominante se centrar nos reinos e nos reis de Castela e de Leão, o desenvolvimento da atenção dada aos reinos periféricos e, em particular, a Portugal, na Crónica de 1344, é um elemento significativo pois vem acentuar a presença destes reinos na história peninsular.

A história dos reis de Portugal é apresentada, de modo muito sintéctico, pela PCG (cap. 969-971) e pela Trad.Gall (cap. 472-473). A Cr20R (cap. iiii a $\mathrm{x}$ do lv. XII) já integra alguns elementos épico-lendários acerca do primeiro rei de Portugal mas é a segunda redacção da Crónica de 1344 que, naturalmente, mais amplifica e prolonga o assunto (cap. DCCV a DCCXXVII). No que se refere às histórias dos reis de Navarra e de Aragão, a Trad.Gall alinha com o texto editado como PCG e com o texto da $\mathrm{Cr} 20 \mathrm{R}^{16}$. Porém, as crónicas portuguesas vão dilatar esta narrativa. No caso da segunda redacção da Crónica de

15 Este assunto é analisado com maior detalhe em DiAs, I. B., «Le Duel des Géants» em Brusegan, R.: et alii, L'Antichitá nella Cultura Europea del Medioevo, Greifswald, Reineke-Verlag, 1998, pp. 195-205.

16 A história dos reis de Navarra e de Aragão, na PCG, termina no cap. 801. Na Cr.20R, termina no cap. xviii [17] do lv. VII da III Parte. Na Trad.Gall, termina no cap. 176. 
1344, o prolongamento vai do capítulo CDXXXVII até ao capítulo CDXLIII, que corresponde aos capítulos 321-326 da primeira redacção, sendo que nesta a continuação ainda se estende pelos capítulos 327 a 331. Este aumento pode justificar-se, meramente pelo acesso a fontes mais detalhadas das histórias daqueles reinos. No entanto, também há que notar que o aumento da extensão textual dedicada aos reinos periféricos altera o peso relativo dos vários reinos, sobretudo, quando também se abrevia, mesmo se discretamente, as narrativas sobre os reis de Castela e de Leão.

A Crónica de 1344 é, pois, mais frugal do que os textos castelhano-leoneses no que se refere aos elogios aos reis que conseguiram unificar reinos. Muitas das narrativas mais ou menos elogiosas relativas aos soberanos mais recentes de Castela e de Leão são frequentemente abreviadas. Concomitantemente, não é esquecido nenhum dos episódios mais nublosos ou humilhantes dos reinados dos soberanos castelhanos e leoneses. Esta atitude tanto pode ser entendida como fruto de uma postura anti-imperial como decorrente de uma ideologia pró-senhorial, consoante os contextos ideológicos dominantes que terão rodeado a redaç̧ão das duas versões ${ }^{17}$. Porém, tanto num caso como no outro, tratase de alterações que não podemos qualificar como inocentes.

\section{c) A amplificatio de narrativas épicas e romanescas}

Ainda na narrativa do período da Reconquista cristã, a cópia do modelo afonsino está pautada, sobretudo na Crónica de 1344, pela inserção de excertos épicos ou romanescos mais extensos ou em versões diferentes. Estas narrativas põem frequentemente em cena os feitos de vassalos poderosos e, muitas vezes, também rebeldes, o que nem sempre ia ao encontro da valorização da posição central e dominante do soberano. Por conseguinte, os textos afonsinos terão tratado estas narrativas com particular cuidado, tendo-as devalorizado com frequência.

17 Considerando que a primeira redacção da Crónica de 1344 terá sido elaborada pelo conde Pedro Afonso de Barcelos, tido como porta-voz da classe aristocrata, que, à semelhança de outras personagens como D. Juan Manuel, não deixaram de marcar ideologicamente a sua obra intelectual; tendo ainda em conta como algumas das reelaborações mais tardias do corpus afonsino já se encontram igualmente marcadas por uma postura pró-aristocrata, é possível, neste contexto, entender as manipulações em causa como fruto e/ou desenvolvimento dessa mesma corrente ideológica. No entanto, para a segunda redacção, e partindo do princípio que esta reelaboração terá ocorrido nos anos 80 do séc. XIV, quando a ameaça de hegemonia castelhana se colocava com bastante premência, os referidos excertos podem facilmente coadunar-se para servir uma ideologia anti-imperial, contrária à união ibérica. Sobre a questão do antagonismo entre a classe senhorial e as tendências centralizadoras da realeza, ver, para o contexto português, KRUS, L.: A concep̧̧ão nobiliárquica do espaço ibérico (1280-1380), Lisboa, Fundação Calouste Gulbenkian / J.N.I.C.T., 1994 e Mattoso, J.: Ricos-Homens, Infanções e Cavaleiros. A nobreza medieval portuguesa nos sécs. XI-XII, Lisboa, Guimarães editores, 1998. 
Tratado e desenvolvido de modo muito diferente, em distintas crónicas, é, por exemplo, a narrativa dos últimos dias de Fernando I, quando este rei decide distribuir o seu território pelos filhos. A partição da Espanha por Fernando I encontra-se muito abreviada na Primera Crónica General, é um pouco mais desenvolvida na Crónica de Veinte Reyes, e atinge uma expressão particularmente longa nos textos portugueses. Paralelamente, as crónicas do centro peninsular insistem na negatividade da divisão e no mal que a fraqueza do rei provoca ao reino. Consoante o ponto de vista adoptado (a favor de uma maior ou menor centralização régia) esta passagem pode ser interpretada, seja como um exemplo negativo de divisão dos reinos (pois dá origem a sangrentas guerras fratricidas), seja como uma situação que retrata um rei influenciável e indeciso que necessita, em absoluto, da presença e do conselho do seu vassalo mais fiel, o Cid (como se verifica no texto que surge nas duas redacções da Crónica de 1344).

Por outro lado, para galegos e portugueses, o excerto tem particular relevância pois Garcia, o filho mais novo de Fernando I, é contemplado com um reino constituído pela Galiza e pela parte já conquistada de Portugal. Assim, esta história constitui um precedente importantíssimo, não só para a ideia da divisão peninsular, como também para justificar a existência e reclamar um pouco mais de antiguidade para o reino mais recente da Península. No entanto, ao confrontar-se com a história da partição dos reinos por Fernando, o Magno, a Crónica de 1344 encontrou sérias dificuldades. Garcia é, efectivamente, rei do Ocidente peninsular. Porém, as crónicas anteriores veiculavam uma tradição negativa sobre a qual, tanto a crónica galega, como as portuguesas tiveram de agir, graças a procedimentos que serão adiante apresentados em maior detalhe.

Outro trecho que retrata alguma fraqueza por parte da realeza face a uma classe nobre valorosa, quando não, ameaçadora, é o da história das «Mocedades de Rodrigo». Na sequência de uma interpolação efectuada na denominada Crónica de Castilla, o ramo das crónicas produzidas no ocidente peninsular também veicula esta narrativa onde a capacidade de acção e decisão do herói contrasta com o carácter temeroso e indeciso do rei Fernando I, que só se torna «Par de Emperador» graças à intervenção do fiel vassalo, que o agracia com a vitória sobre as forças papais e imperiais ${ }^{18}$.

No juramento de Santa Gádea, é ainda o Cid que põe em dúvida os meios mais ou menos lícitos pelos quais o futuro Afonso VI teria chegado ao trono castelhano ${ }^{19}$. Verifica-se um caso semelhante quando o mesmo rei se vê obriga-

18 O texto deste poema encontra-se perdido sob a forma primeira de cantar de gesta mas subsiste numa versão poética tardia: «Rodrigo y el Rey Fernando», MEnÉndez PIDAL, R. (ed.) e Catalán, D. (reed.): Relíquias de la Poesia Épica Española, Madrid, Gredos, 1980, pp. 257-289. A narrativa das façanhas da juventude do Cid foi acolhida pela Crónica de Castilla, passando daí para o ramo ocidental destas crónicas. A PCG e a Cr20R omitem este relato, que foi interpolado entre os caps. 803-4, 804-5, 809-10 e 810-11 da PCG.

19 Cf. cap.ii do lv. X da Cr20R; cap. 845 da PCG; cap. 251-253 da Trad.Gall; cap. 416-18 da 1344a, e cap. 508-10 da 1344b. 
do a ceder face ao Cid devido ao medo que lhe inspirava o poder bélico do vassalo e a possibilidade de poder ter que vir a defrontá-lo ${ }^{20}$.

Este tipo de situação foi acentuado em algumas remodelações pós-afonsinas da Estoria de Espanna onde se nota um ponto de vista mais pro-nobiliárquico. No entanto, os mesmo trechos podem, igualmente, servir os interesses identificados, particularmente, para a segunda redacção da Crónica de 1344, na medida em que, de alguma forma, «diminuem» a imagem de determinados soberanos que, na realidade, unificaram e reinaram sobre grande parte do território ibérico.

Ainda no quadro da desvalorização do poder e da própria personalidade de alguns soberanos, verifica-se que a Crónica de 1344 recolhe as tradições mais longas dos episódios que relatam as rebeldias de alguns cavaleiros, realçados em detrimento da imagem e do valor dos reis que serviam. Um exemplo deste procedimento é a versão mais violenta da história de Fernán González, onde o herói castelhano afronta o seu suserano, o rei de Leão, no processo que conduzirá à independência de Castela ${ }^{21}$.

Finalmente, a história do primeiro rei de Portugal, Afonso Henriques22, também é uma narrativa de cariz épico-romanesco que apresenta o Imperador das Espanhas, Afonso VII, sob um ponto de vista muito desfavorável, sobretudo no que se refere ao seu pouco discernimento e incompetência estratégica e militar. Com a inserção destes relatos, a crónica portuguesa está a fazer o mesmo que antes fora realizado com Fernán González, cuja tradição épica foi aproveitada para a construção de um passado glorioso para Castela. Do mesmo modo, e apresentando traços que posteriormente mais se irão assemelhar ao protótipo castelhano ${ }^{23}$, as lendas relativas a Afonso Henriques construirão o suporte e a justificação do direito de Portugal à sua independência.

20 Esta narrativa foi interpolada entre os caps. 895 e 896 da PCG. Está ausente também da Trad.Gall. A Cr20R refere os conflitos entre o Cid e Afonso VI mas não os completa com qualquer cedência por parte do rei (cf. Cr20R: X, cap. XLVII até bis-LIII). A narrativa mais extensa encontra-se assim na 1344a: caps. 490-97 e 1344b: caps. DLXXXIII - DLXXXIX.

${ }_{21}$ Como o prova o seguinte excerto: «- Callade, rey Sancho Ordonhez! Nõ digades pallavras tã vãas, ca, ẽno que dizedes, dariades pouco recado quando comprisse! Ca digo a Deus verdade que, se nõ fosse por essas tregoas que dizedes que antre nos meteu esse abbade de Sam Fagundo cõ os outros home. es bõos, assi como vos dizedes, que vos cortaria a cabeça e que do sangue do vosso corpo yria esta auga tynta. E tiinhao muy bem guisado pera ho fazer, se ha tregoa nõ fosse. Ca eu estou e. cima deste cavallo e tenho esta spada cinta; e vos andades em hu a mulla e tragedes esse açor e . na mãao» (1344b: III, 99).

22 A história mais desenvolvida dos reis de Portugal é interpolada entre os caps. 979 e 980 da PCG e corresponde aos caps. DCCV-DCCXXVII da 1344b (a história da vida e feitos de Afonso Henriques ocupa os cap. DCCV-DCCXV).

${ }_{23}$ Sobre os desenvolvimentos posteriores das lendas sobre Afonso Henriques ver CINTRA, L. F. L.: "A Lenda de Afonso I, Rei de Portugal (origens e evolução)», ICALP Revista, 16-17, 1989, pp. 64-78 ou Saraiva, A. J.: O Crepúsculo da Idade Média em Portugal, Lisboa, Gradiva, 1998, nomeadamente «A primeira narrativa do milagre de Ourique» (pp. 163-166). 


\section{AlteraÇÕES DE PORMENOR}

Em alternativa à inserção ou à omissão de grandes blocos textuais, bem como à respectiva ampliação ou abreviação, o desvio do sentido de um texto também pode realizar-se ao nível de pequenas alterações de pormenor. Como ocorrem neste nível do detalhe, podem passar despercebidas a uma leitura mais apressada. No entanto, são retoricamente tão ou mais eficientes do que as grandes alterações porque, sendo mais subtis, mais facilmente poderão ser interiorizadas, podendo ainda não só contribuir para veicular ideias e noções, mas ainda minar ideologicamente a narrativa em que ocorrem.

\section{a) A conquista de um espaço na história}

A vontade de conquistar um espaço para Portugal, no imaginário e na memória, graças à historiografia, para justificar o espaço físico já adquirido, pode ser vista em múltiplos pormenores textuais. Logo no Prólogo, a segunda redacção da Crónica de 1344 procede a duas alterações do texto que dá início à «versão régia»: uma omissão e um acrescento, muito significativos. A omissão revela o interesse em fazer esquecer a extensão do reino de Afonso X e, certamente, em particular as referências a territórios, no momento, definitivamente sob alçada portuguesa (sublinhados nossos):

\begin{tabular}{|c|c|}
\hline PCG (versão régia) & Crónica de 1344 (2ª red.) \\
\hline $\begin{array}{l}\text { E por end Nos don Alfonsso, por la } \\
\text { gracia de Dios rey de Castiella, de } \\
\text { Toledo, de Leon, de Gallizia, de Seui- } \\
\text { lla, de Cordoua, de Múrcia, de Jahen } \\
\text { et dell Algarue, ffijo del muy noble } \\
\text { rey don Ffernando et de la reyna don- } \\
\text { na Beatriz, mandamos ayuntar quan- } \\
\text { tos libros pudimos auer de istorias en } \\
\text { que alguna cosa contassen de los fe- } \\
\text { chos dEspanna } \\
\text { (Prólogo - vol. I, p. 4a) }\end{array}$ & $\begin{array}{l}\text { Porende el rey dom Affonso de Cas- } \\
\text { tella, que foy filho del rey dõ Fer- } \\
\text { nando e da raynha dona Beatriz, } \\
\text { mandou ajuntar quãtos livros pode } \\
\text { aver das estorias antigas em que al- } \\
\text { gu. as cousas fossen escriptas dos } \\
\text { feytos d'Espanha. } \\
\text { (cap. I - vol. II, p. 6) }\end{array}$ \\
\hline
\end{tabular}

A adição, que ocorre no fim do resumo que é feito da matéria que será abordada na obra, revela a vontade de chamar as atenções para este espaço geográfico, o desejo de inserir também a zona mais ocidental sob o foco da história (sublinhados nossos): 


\begin{tabular}{|c|c|}
\hline PCG (versão régia) & Crónica de 1344 (2a red.) \\
\hline $\begin{array}{l}\text { Et como fueron los cristianos des- } \\
\text { pues cobrando la tierra; et del danno } \\
\text { que uino en ella por partir los reg- } \\
\underline{\text { nos, por que se non pudo cobrar tan }} \\
\text { ayna; et despues cuemo la ayunto } \\
\text { Dios, et por quales maneras et en } \\
\text { qual tiempo, et quales reyes ganaron } \\
\text { la tierra fasta en el mar Meditarre- } \\
\text { neo; et que obras fizo cada uno, assi } \\
\text { cuemo uinieron unos empos otros } \\
\text { fastal nuestro tiempo. } \\
\text { (Prólogo - vol. I, p. 4b) }\end{array}$ & $\begin{array}{l}\text { e como outrossi foro os cristãaos de- } \\
\text { pois cobrando a terra e do dampno } \\
\text { que receberon por se nõ poder cobrar } \\
\text { tã aginha; e, despois, como a Deus } \\
\text { ajuntou e per quaaes maneiras e em } \\
\text { qual tempo; e quantos e quaaes reys } \\
\text { guaanharõ a terra da parte do mar } \\
\text { Mediterreano e quaaes da parte do } \\
\text { mar Ouciano e que obras fezerom } \\
\text { cada hu. us e. seus tempos assi co- } \\
\text { mo veerõ hu. us empos os outros } \\
\text { ataa o te. po deste rey dom Affonso. } \\
\text { (cap. I - vol. II, p. 7) }\end{array}$ \\
\hline
\end{tabular}

De assinalar, também, a supressão da referência à vantagem da união territorial em detrimento da sua partição, presente no texto afonsino, mas significativamente retirada na cópia portuguesa, que altera o significado da frase. Enquanto que no texto português os cristãos são prejudicados pela lentidão da reconquista, o texto afonsino assume que o dano foi causado pela divisão territorial, razão pela qual a reconquista foi dificultada.

De teor equivalente é a forma como as duas redacções da Crónica de 1344 apresentam a contagem dos reis ibéricos e que não deixa dúvidas quanto à vontade de inserção de Portugal na linha dos reinos mais antigos e mais poderosos da Península:

\begin{tabular}{|l|l|}
\hline Crónica de 1344 ( $1^{\text {a }}$ red.) & Crónica de 1344 ( $2^{\mathrm{a}}$ red.) \\
\hline fueron rreyes de Leon e de Castilla & foron reis de Castella e de Leom trin- \\
que fueron treynta e siete. E los rre- & ta e sete. E, co os reis godos, que \\
yes godos fueron treynta e seys, ansi & foron trinta e seis, fazem sateenta e \\
que son por todos setenta e tres. E & tres. E, com el rey don Garcia e com \\
con el rrei don Garçia e con otros & outros sete que forom reis de Portu- \\
siete que fueron rreyes de Portugal, & gal, foron per toda conta oyte. ta e \\
que fueron por toda cuenta ochenta & hu, u, ataa a era de myl e trezentos e \\
e vno, fasta en la era de mill e tre- & oyteenta e dous annos que este livro \\
zientos e ochenta e dos años que este & foy feito, feria quarta, viinte e hu u \\
libro fue hecho, en miercoles, veynte & dias de Janeiro da dita era (1344b: \\
e vn dias del mes de Henero de la & II, 380). \\
dicha hera. (1344a: p. 199 - ed. & \\
CATALÁN \& ANDRÉS) & \\
\hline
\end{tabular}


No trecho em apreço, é nítido o intuito de valorizar Portugal e os seus reis e de enxertar este ramo na árvore da historiografia anterior, um procedimento idêntico ao da construção de linhagens familiares. No fundo, Portugal, sendo o reino mais recente da Península, está aqui a pôr em prática o mesmo procedimento anteriormente levado a cabo relativamente a Castela. Inicialmente marcada por um estado de vassalagem, como Portugal, Castela conseguiu prestigiar o seu passado igualmente graças ao labor historiográfico, seja pelo recurso às tradições épicas, que absorve, em particular as do ciclo de Fernán González, seja por também se associar à anterior linha sucessiva que procurava ligar, quase sem perturbações, os reis godos aos asturianos, leoneses e, finalmente castelhanos ${ }^{24}$.

$\mathrm{Na}$ sequência destes antecedentes, a melhor maneira como Portugal podia impor ideologicamente a sua presença no espaço Ibérico era tomando posse de um lugar nesse passado, enxertando a sua história numa tradição que a historiografia afonsina já tinha consagrado como predominante na Península Ibérica.

Verifica-se, pois, como o trabalho levado a cabo pelos cronistas portugueses não difere muito do anteriormente realizado nos seus modelos textuais. Porém,

24 O filão neo-gótico foi cultivado primeiro pela historiografia astur-leonesa e posteriormente adoptado pela castelhana, em vernáculo, com Afonso X e ainda pelos textos pós-afonsinos, apesar de já se verificar aqui alguma desconstrução do tema. É de reparar, em particular, como, na PCG se verifica a preocupação em introduzir os reinados dos diversos soberanos com uma referência à sua sucessão relativamente a Pelaio (ex: «El regnado del rey don Ramiro el $\mathrm{II}^{\circ}$, et XVII despues del rey don Pelayo, se comiença.» PCG: II, 389b), o primeiro rei da Reconquista, obviamente um nobre godo escolhido por Deus para comandar as forças cristãs de resistência à invasão muçulmana, reatando assim a ligação privilegiada que unia Deus ao povo godo (que, de certa forma, vai espelhar o povo eleito bíblico) e associar os soberanos da Reconquista a estes antecessores, baseando assim o argumento que justifica a Reconquista como recuperação de uma herança usurpada. Quando Castela passa de condado a reino e adquire importância é associada a esta linha. Acresce ainda, depois de Afonso VII, a significativa acentuação da relação dos diversos reis com o «Imperador» (ex: «Del regnado del rey don Alffonsso, fijo deste rey don Sancho et nieto dell emperador, que regno treynteno despues del rey don Pelayo» PCG: II, 668a). Ainda sobre a questão do neo-goticismo ver as considerações de CATALÁN, D. (1997): acerca da mentalidade subjacente à elaboração do ms. E1(orig). Ver ainda o artigo de GonZÁlez-CASANOVAS, R. J.: «Alfonso X's Concept of Hispania: Cultural Politics in the Histories», em Forde, S., Johnson, L. e Murray, A. V.: Concepts of National Identity in the Middle Ages, Leeds, Leeds Texts and Monographs, 1995, pp. 155-170. Sobre a continuação do espírito neo-gótico concomitante com a divisão da história peninsular nos dois grandes períodos de pré e pós invasão muçulmana ver Krus; L.: Passado, Memória e Poder na Sociedade Medieval Portuguesa, Redondo, Patrimonia Historica, 1994, nomeadamente «Tempo de godos e tempo de mouros - as memórias da Reconquista» (pp. 103-127) e «Os heróis da Reconquista e a realeza sagrada medieval peninsular: Afonso X e a Primeira Crónica Geral de Espanha» (pp. 129142). Sobre estas questões ver ainda as observações dos editores das diversas crónicas asturianas, bem como os respectivos textos: BonnaZ, Y. (ed.), Chroniques Asturiennes (fin IXe siècle), Paris, CNRS, 1987 e Gil Fernandez, J., Moralejo, J. L. e Ruiz de la Peña, J. I. (eds.): Cronicas Asturianas, Oviedo, Universidad de Oviedo, 1985 ou ainda MARTIN, G.: Histoires de l'Espagne médiévale. Historiographie, geste, romancero, Paris, Publication du Séminaire d'études médiévales hispaniques de l'Université de Paris XIII / Klincksieck, 1997 («Un récit (la chute du royaume wisigothique d'Espagne dans l'historiographie chrétienne des VIIIe et IXe siècles)», pp. 11-42.). 
ao contrário do que sucedeu com Castela, não se pretende aqui absorver a tradição anterior para assumir o seu comando, mas sim aproveitar o que dela possa convir aos interesses coevos, se possível, em detrimento do prestígio de vizinhos mais fortes e ameaçadores.

\section{b) A limpeza do bom-nome}

O bom-nome daqueles a quem um dado texto se destina é ponto fundamental e básico a ter em atenção por quem elabora esse mesmo texto. Deste modo, são naturais as diversas manipulações de pormenor que encontramos nas crónicas do ocidente peninsular e que procuram ou reabilitar, ou desculpar ou, simplesmente, extirpar algumas observações menos favoráveis existentes nas suas fontes. Exemplos bem ilustrativos destes procedimentos podem ser encontrados no trecho que narra a história de Garcia, rei da Galiza e de Portugal, filho de Fernando, o Magno ${ }^{25}$. O caso é interessante porque se constata, nas crónicas do ocidente peninsular, alguma hesitação. As referências negativas não são eliminadas liminarmente, certamente, por respeito à autoridade da fonte. Porém, são inúmeras as atenuantes apresentadas ou insinuadas, assim como efectuados pequenos mas significativos desvios de sentido.

\section{- o bom-nome do rei Garcia}

O rei Garcia e a salvaguarda do seu bom-nome interessam a galegos e a portugueses. Para os galegos, Garcia pode representar a memória de um tempo em que aquela região foi um reino independente. Para os portugueses, Garcia, como indica a contagem dos reis presente na Crónica de 1344, acima transcrita, constitui um precedente da independência de Portugal. No entanto, nestas crónicas, Garcia é também o primeiro dos três irmãos que quebra o juramento feito a Fernando o Magno, aquando da partição dos reinos, ao atacar o território da sua irmã Urraca. Na sequência desta divisão de interesses, é notória a alteração de partido que se pode encontrar entre os textos do centro peninsular e os do extremo ocidente. Um testemunho desta alteração é o modo como são apresentados os lamentos de D. Urraca. $\mathrm{Na}$ «versão crítica» e na «versão amplificada de 1289» é patente a revolta da infanta, espelhada na violência da maldição que dirige ao irmão:

25 Para este trecho, a Crónica de Veinte Reyes é testemunho da «versão crítica» (secção 4, que relata a história dos reis de Castela e de Leão, de Fernando I até ao fim do reinado de Fernando II, de acordo com FERnÁNDEZ-OrdóÑEZ, I.: 2000, p. 233) e a Primera Crónica General, entre as pp. 429 e 565 transcreve o ms. do séc. 13 que integra o códice E2 e é testemunha da «versão amplificada de 1289» (cf. FERNÁNDEZ-ORDÓÑ̃Z, I.: 2000, p. 243) 


\begin{tabular}{|l|l|}
\hline Cr20R (versão crítica) & PCG (versão amplificada de 1289) \\
\hline $\begin{array}{l}\text { El rrey don García, que es hermano } \\
\text { menor, me deseredó primero e pasó } \\
\text { el mandamiento e la jura que fizo a }\end{array}$ & $\begin{array}{l}\text { El rey don Garçia, que es mio her- } \\
\text { mano menor, me deseredo primero } \\
\text { que padre. iDeseredado sea él en este } \\
\text { mundo e en el otro!» (Cr20R: 182 }\end{array}$ \\
$\begin{array}{l}\text { passo la yura que fizo a su padre et } \\
\text { lo quel mando et le prometio que } \\
\text { gelo ternie. Ruego a Dios que dese- } \\
\text { redado sea el en este mundo et en ell } \\
\text { otro» (PCG: II, 497a) }\end{array}$ \\
\hline
\end{tabular}

As versões mais ocidentais põem em jogo um elemento novo: o maior temor que D. Urraca teria do irmão mais velho, Sancho II, e do que ele lhe poderia fazer, diluindo assim a questão pelos dois transgressores, o do momento e o que também errará a seguir. Por outro lado, a maldição é atenuada e a sua colocação após a referência a D. Sancho cria alguma ambiguidade relativamente ao seu referente:

\begin{tabular}{|c|c|c|}
\hline Traducción Gallega & rónica de 1344 ( $1^{\mathrm{a}}$ red.) & Crónica de 1344 (2 ${ }^{\mathrm{a}}$ red.) \\
\hline $\begin{array}{l}\text { el rrey dõ Garçia, que } \\
\text { este yrmano menor, } \\
\text { me deserda, et passou } \\
\text { a jura que fezo al rrey } \\
\text { meu padre, el rrey dõ } \\
\text { Sancho, que este o } \\
\text { mayor et que fezo a } \\
\text { jura per força et con- } \\
\text { tradiziendo(a) sempre } \\
\text { a partiçõ, mays querra } \\
\text { y fazer. Et por ende } \\
\text { rrogo a Deus que } \\
\text { çedo seya deserdado. } \\
\text { (Trad.Gall: } 354 \text { ) }\end{array}$ & $\begin{array}{l}\text { pues que el rrey don gar- } \\
\text { çia que es el hermaño } \\
\text { meor me deshereda e } \\
\text { pasa la jura que fizo a el } \\
\text { rrey my. padre e el rrey } \\
\text { don sancho que es el } \\
\text { ma[y]or e le fizieron } \\
\text { agravio e }[\ldots] \text { partición la } \\
\text { qual el con[tra]dixo } \\
\text { ssienpre la partición mas } \\
\text { qujera dios hy fazer lo } \\
\text { suyo e porende le rruego } \\
\text { que el sea desheredado } \\
\text { (1344a: f. 218rb) }\end{array}$ & $\begin{array}{l}\text { Ca, pois que el rei dom } \\
\text { Garcia, que he o irmãao } \\
\text { meor, me deshereda e } \\
\text { passou a jura que fez a } \\
\text { meu padre, que fara el rei } \\
\text { dom Sancho, que he o } \\
\text { mayor e que fez a jura } \\
\text { forçadame te, contradi- } \\
\text { zendo sempre a partiçon? } \\
\text { Mas Deus queira em ello } \\
\text { mostrar o seu direito e } \\
\text { peçolhe mercee que assi } \\
\text { seja elle deserdado! } \\
\text { (1344b: III, 352-353) }\end{array}$ \\
\hline
\end{tabular}

O mesmo tipo de procedimento é visível quando o rei Garcia, uma vez desafiado pelo seu irmão, Sancho II, se lamenta da sua sorte e admite as suas culpas:

\begin{tabular}{|l|l|}
\hline Cr20R (versão crítica) & PCG (versão amplificada de 1289) \\
\hline $\begin{array}{l}\text { El rrey don García, quando esto oyó, } \\
\text { pesóle muy de coraçón e fue muy }\end{array}$ & $\begin{array}{l}\text { Quando esto oyo el rey don Garçia, } \\
\text { pesol muy de coraçon et fue en muy }\end{array}$ \\
\hline
\end{tabular}


cuytado e dixo: «Señor Ihesu Christo, miénbrate el pleito e la jura que fezimos al rrey don Ferrando, nuestro padre, quel que pasase su mandamiento e fuese contra su hermano que fuese traydor por ello e que fuese traydor por ello (sic) e que oviese la yra de Dios e la suya, e, malos mis pecados, yo fuy el primero que lo pasé, ca tomé a mi hermana doña Urraca su heredamiento». (Cr20R: 183a) grand cueyta, et dixo querellandosse a Dios: «Sennor Ihesu Cristo, miembrete del pleyto et de la yura que fiziemos al rey don Fernando, nuestro padre, que quien passasse su mandamiento et fuesse contra su hermano que fuesse traydor por ello et que ouiesse la yra de Dios et la suya. Et malos mios pecados, yo fu el primero que lo passe et tolli a mi hermana donna Vrraca su heredamiento quel el diera». (PCG: II, 498b).

A violência dos termos presentes nas crónicas do centro peninsular é, mais uma vez, substancialmente atenuada nas versões mais ocidentais:

\begin{tabular}{|c|c|c|}
\hline Traducción Gallega & Crónica de 1344 ( $1^{\mathrm{a}}$ red.) & Crónica de 1344 ( (2 ${ }^{\mathrm{a}}$ red.) \\
\hline $\begin{array}{l}\text { Et desto pesou muy- } \\
\text { to al rrey dõ Garçia. } \\
\text { Et dise: } \\
\text { - Senor Ihesu Cristo, } \\
\text { ne brete o preito que } \\
\text { fezemos al rrey, noso } \\
\text { padre; pero mal pe- } \\
\text { cado eu fuy o primey- } \\
\text { ro [que quebrantey] a } \\
\text { jura que fezemos a el } \\
\text { rrey, meu padre, et } \\
\text { tolly per força a mjna } \\
\text { irmaa dõna Orraca } \\
\text { seu herdamento. } \\
\text { (Trad. Gall: } 357 \text { ) }\end{array}$ & $\begin{array}{l}{[\ldots] \text { don garçia }[\ldots] \text { dixo }} \\
\text { señor Ihesu Christo ne } \\
\text { [bre]te del pleyto e de la } \\
\text { jura que fezimos a mio } \\
\text { padre pero mal pecado } \\
\text { yo fue el }[\ldots . .] \text { qebrãte ca } \\
\text { tome por fuerça a my } \\
\text { hermaña dona U[...]os } \\
\text { heredamentos (1344a: } \mathrm{f} . \\
219 \mathrm{rb})\end{array}$ & $\begin{array}{l}\text { E, quando dom Garcia } \\
\text { esto ouvyo, disse: } \\
\text { - Senhor Jhesu Cristo, } \\
\text { nembrete o preyto e ju- } \\
\text { rame. to que fezemos a } \\
\text { nosso padre, como quer } \\
\text { que eu fuy per minha } \\
\text { maldade o primeiro que o } \\
\text { britey, por que tomey per } \\
\text { força a mynha irmã os } \\
\text { seus herdamentos } \\
(1344 \mathrm{~b} \text { : III, 355) }\end{array}$ \\
\hline
\end{tabular}

Finalmente, bastante ilustrativo deste processo é ainda a evolução da frase que retrata o rei Garcia e que começa por ser, na «versão crítica», uma observação que dá entrada à questão do mau relacionamento que Garcia manteria com os seus vassalos ${ }^{26}$ : «E el rrey don García era omne muy fuerte e muy bravo

26 O mau relacionamento de Garcia com os seus vassalos é um tema recorrente nos diferentes testemunhos desta história que se repercute, por exemplo, no facto curioso de Garcia, antes de entrar em combate, fazer um discurso a portugueses e outro a galegos, separadamente, o que poderá ser um indicador da existência de facções e de interesses distintos. O problema é, no entanto, desculpado graças ao argumento da ingerência de um conselheiro demasiado influente. Sobre o topos 
contra los suyos,» (Cr20R: 202b). Porém, na «versão retoricamente amplificada» passa a ilustrar uma característica física de Garcia o que, certamente, reverteria na maior glória de quem o vencesse: «Este don Garçia como quier que era el hermano menor, era muy fuerte segund dize la estoria», (PCG: II, 499a). Finalmente, nas crónicas do ocidente peninsular, a mera força física é transformada em coragem, para glória de quem a possui: «El rrey dõ Garçia era ome de grã curaçõ.» (Trad.Gall: 358), «Dize la estoria que el rrey don gar[çia] era honme de gran cora[çon]» (1344a: f. 219va) e «ca elle era home. de grande coraçõ e pera grandes feitos.» (1344b: III, 356).

\section{- o bom-nome de galegos e de portugueses}

A par da defesa do bom-nome do rei Garcia, parece situar-se a defesa do bom-nome das populações em causa. Menos atacados, os galegos são, no entanto, diminuídos num conselho que o Cid dá ao rei Sancho II. Curiosamente, este trecho é mantido, também na Trad.Gall, se bem que numa versão um pouco mais diluída ${ }^{27}$. Já no que toca aos portugueses, uma grave crítica surge na boca do rei Fernando, o Magno aquando da partição e que consta no texto da «versão crítica»:

Dio a don García, el menor, toda Gallizia con aquello mesmo quél ganara en Portugal, alabando mucho a los gallegos e a los portogaleses, diziéndoles que eran loçanos, rricos e nobles, francos e leales e caualleros mucho esfforçados en armas, e que nunca ovieron señor de que fuesen abondados nin nunca el señor que ovieran de guardar fuera arrancado. Pero dizen que dixo allí a los portogaleses vna escatima, que nunca fizieran buen señor que entre las manos les cayese; (Cr20R: 173b)

do mau conselheiro e da sua utilidade para a desculpabilização, nomeadamente, do mau governo de um soberano, ver Dias, I. B.: «On royal Infallibility», Portuguese Studies, 15, 1999, pp. 42-51.

27 A Cr20R / «versão crítica» apresenta o texto mais incisivo contra os galegos: «"Señor, los gallegos están agora con el rrey don Alfonso, vuestro hermano, seguros de sus posadas, e non se catan de vos. E vos fazet tornar los que fuyen e acogeldos todos a vos, e cras, quando el alua, ferit en la hueste del rrey don Alfonso a desora, ca los gallegos han por costunbre de se alabar mucho quando son bienandantes, e de chufar e fazer grandes nueuas, e de escarneçer de los otros, e cansarán fablando en ello toda la noche e escontra la mañana adormeçerse han"» (Cr20R: 185b). As restantes crónicas matizam a questão, referindo-se também aos leoneses e, no caso da PCG, ainda aos asturianos (PCG: II, 502b). O excerto que aparece na Trad.Gall mantém as alusões negativas aos galegos: «Et, senor, fazede agora [acoller] a gente que vem fogindo et falade cõ elles et esforçadeos. Et, senor, cras a la madrugada dade cõna signa no canpo; ca elles estam com.o seguros, porque teem que am vençudo pola bõa andãça que am avida. Et demays que os galegos et os leoneses som muy chufadores et de grã parauoa, et estã cõ el rrey seu senor gabãdose da (da) bõa andenaça que ouuerõ, que dize . mays ca deue . Et, se(u) Deus quiser, o grã plazer que elles ouuerõ tornarselles a en pesar» (Trad.Gall: 365-366). Na Crónica de 1344 o trecho ocorre no cap. 385 da $1344 \mathrm{a}$ e no cap. CDLXXXIV da $1344 \mathrm{~b}$. 
O excerto não se encontra, nem na PCG (cf. cap. 213), nem na Trad.Gall (cf. cap. 204) que apresentam este momento de forma muito sintetizada. As duas versões da Crónica de 1344 amplificam o relato da morte de Fernando I, a partição dos reinos a que o rei procede e as situações mais tensas e confusas a que essa divisão dá origem. Porém, significativamente, o excerto é liminarmente esquecido ${ }^{28}$.

No entanto, o eco deste «defeito» vai reaparecer, de forma explícita, nos discursos que Garcia faz aos portugueses, separadamente, antes de combater Sancho II, tanto na «versão crítica», como na «versão amplificada de 1289»:

\begin{tabular}{|c|c|}
\hline Cr20R (versão crítica) & PCG (versão amplificada de 1289) \\
\hline $\begin{array}{l}\text { Des y dixo luego a los portogaleses: } \\
\text { «Amigos, vos sodes nobres caualle- } \\
\text { ros e loçanos, e a menester que todo } \\
\text { el mal pres que avedes que lo perda- } \\
\text { des agora aquí e que finque en vos el } \\
\text { bueno el bueno (sic); ca vos avedes } \\
\text { pres que fazedes pocos señeros bue- } \\
\text { nos, pues fazed oy bueno de my e } \\
\text { será la vuestra onrra muy grande, e } \\
\text { sy yo bien saliere de aquí galardona- } \\
\text { ruos lo he muy bien». E ellos le dixe- } \\
\text { ron que lo farían muy de grado e } \\
\text { que lo ayudarían quanto pudiesen e } \\
\text { que non fincaría por ellos. (Cr20R: } \\
184 a \text { ) }\end{array}$ & $\begin{array}{l}\text { et dixo luego a los portogaleses: } \\
\text { «amigos, uos sodes nobles caualleros } \\
\text { et loçanos, et a mester que tod el mal } \\
\text { prez que auedes que lo perdades oy } \\
\text { aqui, et que finquedes con buen prez; } \\
\text { et departo uos lo: vos avedes prez de } \\
\text { fazer pocos sennores buenos entre } \\
\text { uos; pues fazet uos oy bueno de mi, } \\
\text { ca sera uuestra onrra; et si yo bien } \\
\text { salir daqui, gualardonaruos lo e muy } \\
\text { bien, de guisa que entendredes que a } \\
\text { coraçon e de uos fazer grand algo». } \\
\text { Et ellos dixieronle que lo farien muy } \\
\text { de coraçon, et quel ayudarien quanto } \\
\text { mas pudiessen, que non fincarie por } \\
\text { ellos. (PCG: II, 500a) }\end{array}$ \\
\hline
\end{tabular}

Neste caso, a Traducción Gallega ainda não se afasta muito do modelo afonsino:

Desi apartou os portugeeses et disollis:

- Uos sodes nobles caualeyros et louçaos, et a mester que todo o mal prez se perca oge aqui et que fique sempre o boo, ca uos auedes preço de fazer poucos senores boos. Et ontre uos conue. que façades oge boo de mj., et seera uosa onrra et uosa prol; et, se eu ende sayr, galardoaruolo ey muy be., en guisa que entenderedes que ey sabor de uos fazer algo.

Et elles diserõ que o ajudariaã et o seruiriã de grado quanto podese ., et que nõ ficaria per elles. (Trad. Gall: 360)

No entanto, e como seria de esperar, o mesmo já não sucede nas duas versões da Crónica de 1344. Em que consiste o «mau prez» aludido, não só não é indica-

28 Cf. cap. 364-369 da 1344a e CDLXVIII-CDLXXII da 1344b. 
do, como ainda a expressão adquire, na segunda redacção, um tom geral e indefinido que, como tal, perde o seu anterior valor, então bem concretizado e explicado. A especificação que é feita do valor dos portugueses é, agora, de tom bastante positivo e a anterior insinuação de maus vassalos é aqui transformada numa defesa da liberdade e da independência: os portugueses são apresentados como nobres, ousados e que não aceitam jugos, um tom bem distante do dos restantes textos.

\begin{tabular}{|c|c|}
\hline Crónica de 1344 (1 $1^{\mathrm{a}}$ red.) & Crónica de 1344 (2 $2^{\mathrm{a}}$ red.) \\
\hline $\begin{array}{l}\text { E desi apartose con los portogaleses e } \\
\text { dixoles amigos vos ssodes nobles } \\
\text { honbres e a menester que todo el } \\
\text { mayor pres que el dia que [...] sse } \\
\text { gane aq? e finque en vos sienpre todo } \\
\text { bien ca vos avedes pres de ardidos e } \\
\text { que non queredes entre vos muchos } \\
\text { sseñores e conviene que hagades hoy } \\
\text { bueno de my e sera vuestra honrra e } \\
\text { vuestra pro e si dende yo ssaliere bibo } \\
\text { yo vos lo galardonare muy bien en } \\
\text { guissa que entendades el talante de } \\
\text { vos fazer bien end e ellos dixeron que } \\
\text { lo servirian e lo ayudarian de grado } \\
\text { quanto podiesen e que non fincaria } \\
\text { por ellos (1344a: f. 220ra-b) }\end{array}$ & $\begin{array}{l}\text { Desi apartousse cõ os Portugueses e } \\
\text { disselhes: } \\
\text { - Amigos, vos sodes nobres home . es; } \\
\text { faz mester que todo maao prez se perca } \\
\text { oje aqui e fique e. vos bondade pera } \\
\text { sempre, ca vos avedes prez d'ardidos e } \\
\text { nõ queredes antre vos muitos senhores. } \\
\text { Pore. vos cõvem que façaaes oje de } \\
\text { my. boo e seera grande vossa honrra e } \\
\text { muita vossa prol, ca, se eu ende vivo } \\
\text { sayr, eu vollo gallardoarey mui bem, de } \\
\text { tal guisa que entendades que eu hey } \\
\text { tallante de vos fazer mercee. } \\
\text { E elles diseron que o serviriã e ajudariã } \\
\text { de grado e que nõ ficaria per elles. } \\
\text { (1344b: III, 358) }\end{array}$ \\
\hline
\end{tabular}

Graças a estas estratégias, a Crónica de 1344 consegue inclusivamente mitigar a derrota com que termina o reinado de Garcia. Nos diversos textos, o «defeito» dos portugueses é referido e reiterado até à sua exemplificação prática na fuga inglória que contribui para a derrota do rei Garcia: «mas al cabo vençiéronse los portogaleses e desanpararon su rey e fuxeron,» (Cr20R: 185a), «mas al cabo desanpararon los portogaleses al rey don Garcia, et fuxieron;» (PCG: II, 502a) e «Mays desempararõ en cabo os portugueeses al rrey dõ Garçia et fogirõ.» (Trad.Gall: 364). Porém, as duas redacções da Crónica de 1344, não eliminando o facto dos portugueses terem «desamparado» o rei Garcia, suprimem o pormenor da fuga (e da respectiva vergonha que tal acto acarretava...) e dão a entender, pela expressão «a cima» (cf «acima de tudo») que foi esta perda de suporte a principal razão da derrota de Garcia que, sem tal ajuda, não poderia senão perder a batalha: «mas a la cima desanpararõ los portogaleses al rrey don garçia» (1344a: f. 221va) e "Mas aa cima desempararõ os Portugueses el rei dom Garcia.» (1344b: III, 362).

Levando ainda mais longe este exercício de defesa dos portugueses, o texto refundido do Livro de Linhagens do conde D. Pedro não parece apresentar qual- 
quer prurido em manipular ainda mais profundamente estas tradições em prol dos seus interesses. $\mathrm{O}$ relato centra-se aqui no herói Rodrigo Foiaz, apresentado como um líder autonómico que remonta aos tempos do rei Garcia ${ }^{29}$. Rodrigo Froiaz é o campeão daqueles a quem o texto chama obstinada e repetidamente de «mui boos fidalgos portugueses», para que ninguém se esqueça ${ }^{30}$.

Neste texto, o tom pró-português é levado consideravelmente mais longe. Garcia é apresentado como um rei que, apesar de, por vezes, se deixar influenciar mal, não é, por isso, pior servido pelos seus vassalos, fiéis e dedicados até às últimas consequências. E se o seu fim se revela trágico, esse facto não foi causado por falta de esforço mas pela confluência de uma série de sucessos infelizes ${ }^{31}$.

\section{- o bom-nome dos povoadores do Porto}

Outra situação onde se encontra patente a vontade de sanar alusões menos abonatórias que remetam para o reino português e para as suas gentes é a que se verifica a propósito dos primeiros povoadores do Porto e na consequente explicação da origem do nome «Portugal».

A explicação do nome do reino surge, pela primeira vez, quando se fala dos primórdios da povoação do Mundo, na sequência da dispersão dos gigantes de Babel. Neste ponto, talvez por causa do peso da Autoridade bíblica subjacente, não houve coragem para alterar ou cortar o texto afonsino que se traduzia:

\begin{tabular}{|l|l|}
\hline PCG (versão régia) & Crónica de 1344 (2 ${ }^{\mathrm{a}}$ red.) \\
\hline e los otros que llamaron galaicos po- & E outros que chamarõ Gallicios po- \\
blaron Galizia, que antiguamientre & brarõ Galliza, a qual antigamente \\
solie seer desdell agua de Cea fastal & soya de seer des augua de Cea ataa o \\
puerto de Gaya. Despues uinieron & porto de Gaya.
\end{tabular}

29 Sobre este assunto, ver KRUS, L.: A concep̧̧ão nobiliárquica do espaço ibérico (1280-1380), Lisboa, Fundação Calouste Gulbenkian / JNICT, 1994, pp. 281-286.

30 Ver Mattoso, J. (ed.): Pedro Afonso, conde de Barcelos, «Livro de Linhagens do Conde D. Pedro», Portugaliae Monumenta Historica Nova Série, Lisboa, Academia das Ciências, 1980, 2 vols. A expressão «boos fidalgos de Portugal» é reiterada quatro vezes entre as pp. 226 e 228 ( $1^{\circ}$ vol.), encontrando-se ainda a sua expansão como «estes boos fidalgos de Portugal, que sempre forom boos aos senhores e amarom verdade» (p. 228).

31 Note-se que o tema da infelicidade / má sorte já surge nas crónicas do ocidente, nomeadamente quando Garcia prende o seu irmão Sancho e o dá a guardar a uns cavaleiros que não serão capazes de o manter em prisão: «Et foy en ello de mao acordo et de maa ventura» (Trad.Gall: 362), «E fue porende de mal rrecabdo e de mala ventura» (1344a: f. 221 ra) e «E por esto foy home . de maao recado e de fraca ventuira» (1344b: 361). Na «versão crítica» diz-se: «mas fue en ello engagañado e omne de mala ventura». (Cr20R: 184b) e na «versão amplificada de 1289» diz-se «et dize la estoria que fue en ello de mal acuerdo» (PCG: ii, 501a), acentuando-se a desvalorização da capacidade de discernimento e a opção tomada pelo rei Garcia. 
galeses por mar, que eran echados de su tierra, e arribaron a un logar que agora llaman Puerto, e poblaron una grand partida de Galizia que era yerma entre los dos rios que llaman Duero e Minno, e pusieron le nombre Portugal. (PCG, I: 6b)
E despois per tempo arrybaron onde agora chamã o Porto hu as gentes e. naves que eram degradados de sua terra, os quaaes eram chamados Galases. E estes pobrarom hu. a grande parte de Galliza que era herma, e esta era antre doous ryos que chamam a hu. u Doiro e outro Mynho. E composerom estes dous nomes e entom poserom nome aa terra Portugalases mas depois o e. curtaron e poseronlhe nome Portugal. (1344b: II, 14-15)

A explicação inicial refere que os primeiros povoadores do Porto vieram degredados, o que não poderia agradar. Por isso, com a desculpa de que o leitor poderia não ter entendido a explicação que surge no início do livro, é inserido um novo trecho explicativo que vai contrariar o anterior, apesar de remeter para ele. Esta versão da história não aparece no texto editado como PCG, nem na Cr20R, nem na Trad.Gall. Só se encontra uma versão bastante mais sintética, no ms. da tradução da primeira redacção da Crónica de 1344 (cap. 452), e na sua $2^{\mathrm{a}}$ redacção, onde integra um capítulo intitulado, precisamente, "como e por qual razõ chamarõ o cõdado de Portugal» (cap. DXLI). Aqui, a referência menos abonatória é liminarmente erradicada, verificando-se uma nítida evolução da primeira para a segunda redacção da Crónica de 1344, pois onde na primeira se faz uma alusão breve, a segunda redacção amplifica consideravelmente:

\begin{tabular}{|c|c|}
\hline Crónica de 1344 ( $1^{\mathrm{a}}$ red.) & Crónica de 1344 (2ª red.) \\
\hline $\begin{array}{l}\text { Dize el cuento q[ue] por la foz } \\
\text { de duero arriba entravan barcas se- } \\
\text { gun la menera que agora entran e } \\
\text { venjan ally aportar do agora esta el } \\
\text { puerto allj a so gaya q[ue] era muy } \\
\text { bue. castillo como agora el e apor- } \\
\text { tavan hy cotrossi e porq[ue] aporta- } \\
\text { va hy pussieron ala villa nonbre el } \\
\text { puerto de portogall e poresso quan- } \\
\text { do el rrey don alfon[so] dio esta tie- } \\
\text { rra del condado del conde don an- } \\
\text { rriq[ue] mando q[ue] llamasen el } \\
\text { condado portogal. (f.250vb) }\end{array}$ & $\begin{array}{l}\text { Contado avemos ja e. os primei- } \\
\text { ros cadernos deste livro, onde falla } \\
\text { das pobraçõoes das terras, como e } \\
\text { por que razõ foy chamado Portugal. } \\
\text { Mas, por que os que leessem e. este } \\
\text { logar e nõ em aquelle outro ficariam } \\
\text { dovidosos, pore. queremos aqui di- } \\
\text { zer algu. a cousa como foy achado } \\
\text { este nome. E devedes de saber, que, } \\
\text { quando se as terras começarõ de po- } \\
\text { brar, em as partes de Galiza foy logo } \\
\text { pobrado acerca Doyro o castello de } \\
\text { Gaya. E, por esto, os pescadores de } \\
\text { Galliza e das outras partes d'arredor }\end{array}$ \\
\hline
\end{tabular}




\begin{tabular}{|l|l|}
\hline & $\begin{array}{l}\text { e . travam per o Doiro em suas barcas } \\
\text { e viinhã a Gaya vender o seu pesca- } \\
\text { do. E despois passavansse da outra } \\
\text { parte, per que era bõo logar e de boa } \\
\text { area pera estender as redes e folgar. E } \\
\text { por esto poserom nome, aaquele lo- } \\
\text { gar em que assi aportavã, Porto. E, } \\
\text { despois per tempo, foy ally pobrada } \\
\text { hu . a villa e chamaronlhe o Porto. E, } \\
\text { despois que hy aportarõ os Gallases } \\
\text { em suas naves, foy posto nome aa } \\
\text { terra Portugal. (1344b: IV, 5) }\end{array}$ \\
\hline
\end{tabular}

\section{c) A supremacia no jogo com as palavras}

Para a formação do quadro ideológico que indicámos para a Crónica de 1344, em particular, na sua segunda redacção, o trecho mais importante é, sem dúvida, o que relata a história dos reis de Portugal e, em particular, a narrativa do complexo lendário, que se formou em torno de Afonso Henriques, o rei Fundador ${ }^{32}$.

A narrativa que surge no texto editado como PCG é lacónica e, além de informações genealógicas, centra-se na indicação de que este rei ousou atacar o rei Fernando II de Leão, tendo sido por ele derrotado (PCG: II, 650-52). O assunto é ainda retomado adiante, quando se fala do reinado de Fernando II (PCG: II, 675-676). A Traducción Gallega segue, nos seus traços gerais, o modelo da PCG. No entanto, já altera um pouco o relato, no que se refere à derrota de Afonso Henriques, como veremos adiante (Trad.Gall: 689-91 e 720-22).

A Crónica de Veinte Reyes, por seu turno, apresenta um texto mais desenvolvido, inserindo alguns episódios épico-lendários, em particular no que se refere à posição de força que Afonso Henriques toma relativamente ao clero. No entanto, são minorados ou mesmo completamente omitidos os relatos onde Afonso Henriques se impõe face ao primo, o Imperador Afonso VII. Apesar de ser mantida a referência à batalha de Arcos de Valdevez, onde o poder de Castela, Leão, Aragão e Galiza é vencido pelo rei português, é omitida a narrativa da subsequente tentativa de vingança por parte do Imperador que vem cercar

32 Sobre estas lendas ver CinTRA, L. F. L. (ed. Cr. 1344), op. cit., vol I (Introd.), SARAiva, A. J.: A Épica Medieval Portuguesa, Lisboa, ICALP, 1979 e Mattoso, J.: Portugal Medieval - Novas interpretações, Lisboa, IN-CM, 1985, pp. 509-435 («João Soares Coelho e a Gesta de Egas Moniz») e idem, "As Três Faces de Afonso Henriques», Penélope, 8, (1992), pp. 25-42. Sobre as tradições subjacentes a Afonso Henriques, ver ainda DiAS, I. B.: «Ares, Marte, Odin...» em WARD, A.: Teoría $y$ práctica de la historiografía hispánica medieval, Birmingham, The University of Birmingham Press, 2000, pp. 80-98. 
o primo em Guimarães, onde é «enganado» por Egas Moniz, trechos que só vamos encontrar na historiografia portuguesa.

Os testemunhos portugueses que, neste período, veiculam, com diferentes graus de desenvolvimento, as narrativas épico-lendárias sobre Afonso Henriques são o Livro de Linhagens do Conde D. Pedro, as III e IV Crónicas Breves de Santa Cruz de Coimbra ${ }^{33}$ e a segunda redacção da Crónica de 1344. Infelizmente, o ms. mais completo da primeira redacção desta crónica termina truncado imediatamente antes de se dar início à história dos reis de Portugal, razão pela qual, sobre este testemunho, só podemos tecer conjecturas ${ }^{34}$.

Em todo o caso, para exemplificar o trabalho de manipulação que os diferentes cronistas terão feito neste passo da história, vamos centrar-nos no episódio do desastre de Badajoz.

A sequência dos acontecimentos ocorridos em Badajoz é sensivelmente a mesma: apesar de esta cidade ser conquista atribuída a Leão, Afonso Henriques toma-a aos mouros. Ao ter conhecimento do facto, Fernando II move para aí o seu exército para combater o rei português. Este, ao passar pela porta da cidade, embate contra o ferrolho e parte uma perna, sendo preso pelo rei leonês que, posteriormente, o liberta em condições específicas. Porém, as diversas crónicas vão conseguir contar este mesmo episódio de forma bastante distinta ${ }^{35}$.

A versão onde os portugueses e o seu rei são mais maltratados é, indiscutivelmente, a que se encontra na PCG. A derrota adquire um peso considerável, não só porque se trata de um episódio que é contado duas vezes, mas também porque a restante matéria sobre o primeiro rei de Portugal é menos extensa e menos gloriosa. A primeira alusão ao episódio encontra-se na narrativa dos reis de Portugal e estabelece, desde logo, a imagem dos dois intervenientes: atrevido um, piedoso o outro:

Este rey don Alffonsso otrossi se atrouo a lidiar con el rey don Fernando de Leon, et fue uençudo este rey don Alffonsso et preso; mas el rey don Fernando era piedoso et soltole luego de la prision et diole a los suyos. (PCG: II, 652a-b)

\footnotetext{
33 As quatro «Chrónicas Breves e memórias avulsas de S. Cruz de Coimbra» foram editadas nos Portugaliae Monumenta Historica. Scriptores, Lisboa, Academia das Ciências, 1856, pp. 23-32.

34 O penúltimo cap. do ms. 2656 da B.U.S. anuncia, à imagem da Trad. Gall, que vai contar a história dos reis de Portugal mas deixa então de seguir a Trad.Gall que, efectivamente, faz aí um resumo da linhagem dos reis de Portugal e das batalhas de Afonso Henriques (semelhante à PCG). O texto do ms. 2656 salta esses dois caps. e a partir do início do seu último cap. retoma o texto, idêntico ao cap. 474 da Trad.Gall e ao cap. 702 da 1344b, terminando de seguida. Torna-se assim muito difícil saber se a história narrada em 1344b também se encontraria em 1344a (nos mesmos moldes ou em moldes diferentes). Por um lado, a omissão dos dois caps., anunciados à semelhança da Trad.Gall, pode fazer pensar que sim, por outro lado, a grande colagem do texto de $1344 \mathrm{a}$ a uma narrativa semelhante à veiculada pela Trad.Gall pode fazer suspeitar que não.

35 Esta cena e suas implicações textuais e ideológicas já foram estudadas por CiNTRA, L. F. L.: (ed. Cr. 1344), op. cit., vol I (Introd), pp. XC, CCCLXI-XII e CCXXXVIII-CCXL, e por CATALÁN, D.: (1962).
} 
Seguidamente, já na história de Fernando II, há notícia de um primeiro confronto com portugueses, em Ciudad Rodrigo, onde estes fogem ingloriamente ou se rendem e relativamente aos quais Fernando II procede com a sua já habitual piedade:

Et lidiaron alli, et uençio la fazienda ell rey don Fernando de Leon, et fuxieron los portogaleses et fincaron dellos muchos muertos alli, et los otros fueron sagudados; los que fincauan aun en el campo echaronse a mesura del rey don Fernando, et el reçibiolos et non les fizo como quen los vençie en batalla mas como piadoso prinçep, et dexolos yr (PCG: II, 675a)

Finalmente, o desastre de Badajoz é contado de forma absolutamente desfavorável à dignidade do rei português. Afonso Henriques surge-nos como um homem amedrontado que, na ânsia da fuga, cai numa situação miserável, de meter dó. Uma vez preso, não hesita em prometer tudo o que tem para se salvar. Fernando II, pelo contrário, limita-se a demonstrar a sua magnanimidade:

Et llego mandado desto a esse rey don Fernando de Leon; et el rey don Fernando, ayuntada su hueste, ueno et lidio con don Alffonsso, rey de Portugal, et uençiol. Et alli fue desbaratada la hueste de los portogaleses, et don Alffonsso su rey fuxo et metiosse en Badaioç, ca ya auie tomado fascas las dos partes dessa çipdad de Badaioç, et tenie los moros encerrados en una torre. Mas nin aun alli non se teniendo por seguro, pues que fuye, ueno a la puerta de la çipdad que se cerraua con pestiello de fierro, et puxo ell al pestiello por abrir la puerta et salir, mas non se abrio bien la puerta, pero salio et rey, mas tanta fue ell angostura de la puerta que crebo alli la pierna al rey, et el apenas pudo salir en el cauallo que nun cayesse del a tierra. Et fue preso luego, et assaz mal parado, et en guisa de auer merçet del todo omne bueno que atal le uiesse; et fue atal empresentado al rey don Fernando et el rey don Fernando reçibiol bien et con piedad et assentol consigo en el su estrado real. Et don Alffonsso, rey de Portugal, mesurando alli estonçes ell su estado et el peligro en que era, conffesso et dixo que uuscara corroto, non deuiendo nin auiendo derecta razon por que contral rey don Fernando de Leon fuesse; et por ende por fazierle emienda offreçiol alli el regno et la su persona, et dauagelo todo. Mas el rey don Fernando mansso et con la piedad que solie, touosse por abondado de lo suyo quel su padre le dexara et de lo que el auie ganado, et de lo desse rey don Alffonsso de Portogal non quiso retener ninguna cosa. Estonçes alli otrossi este rey don Alffonsso de Portugal solto a don Fernando, rey de Leon, tierra de Limia et Turon et otros lugares que deuuien seer del sennorio de don Fernando, rey de Leon, maguer que esse don Alffonsso, rey de Portugal, estonçes de nueuo lo ganara de moros, et dexogelo alli libre et quito sin toda otra contienda el rey don Alffonso al rey don Fernando. Ffecha esta abenençia, et delindados sus terminos e puestos sus amores entre los reyes, finco suelto don Alffonso, rey de Portugal, et tornosse por su tierra. Et dalli adelant este rey don Alffonsso de Portugal non pude usar de fecho de caualleria por razon de la pierna quel crebara en la sallida de la puerta de Badaioç como dixiemos. (PCG: II, 675a-b) 
A Crónica de Veinte Reyes já não se revela tão desfavorável. Além de omitir a primeira referência, na história do rei de Portugal (cf. cap. X do lv. XII), certamente fruto do cuidado tido para não repetir acontecimentos, atenua o pormenor da fuga na batalha de Ciudad Rodrigo ${ }^{36}$ e a presença de Afonso Henriques em Badajoz é apresentada de modo consideravelmente mais digno, provavelmente por influência dos testemunhos lendários que a «versão crítica» terá conhecido. O rei português é um cavaleiro valoroso que tem um infortúnio, consequência da questão havida com a sua mãe. O encontro entre os dois soberanos está marcado por uma certa cortesia mútua:

El rrey don Ferrando luego que lo supo, sacó su hueste e fue sobre el rrey de Portugal e posó a vna legua de la villa. Los caualleros del rrey don Alfonso dixeron: «Señor, hevos aquí el rrey don Ferrando do viene sobre vos con gran hueste». El rrey don Alfonso les dixo: «Pues armémosnos e vayamos a él al campo». El rrey don Alfonso seyendo ya armado, firió al cauallo de las espuelas e fue por salir por la puerta, e el portero quando avrió la puerta non enpuxó el berrojo adentro. El rrey saliendo muy rrezio por la puerta, fue a dar de la pierna en el berrojo e quebróle la pierna. Esto fue por el pecado quél fiziera cont[r]a su madre, e cayó luego fuera de la villa en vn centeno que y avíe. Don Ferrand Rruys el Castellano, que lo vio, fue para el rrey don Ferrando e díxole: «Señor, aquí yaz el rrey don Alfonso con su pierna quebrada, e prendelde». E fue logo preso e leuado al rrey don Ferrando. El rrey don Ferrando rreçibiólo muy bien e asentóle cabo sy. El rrey de Portugal teniéndose por muy quebrantado e que errara mucho contra el rrey don Ferrando, e por fazerle gran emienda dáuale el rreyno e su cuerpo, que él fiziese ende a su plazer. Mas el rrey don Ferrando, commo era manso e muy piadoso, non quiso nada de lo suyo, mas díxole quel diese todo lo suyo. Des y fizole el rrey de Portugal pleito e omenage que tanto que caualgase que fuese a él o que quier quél mandase. Des y otorgó al rrey don Ferrando de Lunia (sic) e de Toroño e de todo lo ál que fuera suyo, e asy le dexó yr el rrey don Ferrando en paz. El rrey don Alfonso de Portogal fuese entonçes para Coynbria e por achaque de la pierna nunca quiso caualgar en todos sus días nin salió de Coynbria fasta que murió. (Cr20R: 276a-b)

A Traducción Gallega vai alinhar com o texto da PCG mas já não apresenta uma narrativa tão demolidora quanto a desta versão, seja no que se refere a Ciudad Rodrigo, onde não refere que os portugueses fugiram ${ }^{37}$, seja no que toca a Badajoz, onde o rei português não é apresentado de forma tão miserável, apesar de quebrar a perna quando tenta fugir ${ }^{38}$, ou seja, no mesmo sentido que nos apa-

36 «e allí lidiaron, e vençió el rrey don Ferrando a los portogaleses, e mató muchos e siguió los otros e prendió muchos. Mas el rrey don Ferrando, commo era omne piadoso, soltólos luego e dexólos yr sua vía». (Cr20R: 276a).

37 «et forõ os de Portugal vençudos; et matou et prendeu moytos delles et seg[u]do[u] os outros, en tal maneyra que foy muy grã seu dãno. Et com. o el rrey era muy piadoso soltou os presos et mandoos yr sua vya». (Trad Gall: 721).

38 «et, quando o soube, pesoullj muyto, et sacou logo sua oste, et foysse para ala. Et lidarõ çerca da villa. Et foy vençudo el rrey de Portugal et foy fugindo contra a vila, et a gente del rrey dõ 
rece na PCG e em sentido contrário ao da versão da Cr20R. No entanto, a principal alteração surge na questão do acordo que é feito entre os dois reis e que a Trad.Gall conta por duas vezes, tal como sucedia na PCG (sublinhado nosso):

\section{Traducción Gallega (hist. de Af. H.) $\quad$ Traducción Gallega (hist. de Fern. II)}

Et este rey lidou en batala cõ el rey dõ Et el rrey de Portugal teuesse por Fernãdo de Leom et foy vençudo et culpado, et arrepenti[u]sse muyto preso. Et, quando o prenderõ, tijna a [por que se mouera] contra el rrey dõ perna britada. Et troixe preyto cõ el Fernando, et pediulli por merçee que rey dõ Fernando, que o soltase et, tal lle perdõasse. Et el rrey dõ Fernando ora com .0 fosse são, que caualgasse era ome de boo talente et piadoso et en besta, que sse ueria a sua priiom. Et nõ quiso ne . hu . a cousa de seu senel rey dõ Fernando coube seu rrogo; et horio; mays ouue avijnça cõ elle, que el fezo menagem de o conprir; et lei- llj desse o que tijna tomado en Galiza, xoo yr pera seu rreynado a Portugal. et que o soltasse, et que o leixasse yr a Et são [u] muy bem [et] nu. ca ia sua terra guareçer da perna; et logo mais quiso caualgar en besta, por nõ com . o fosse são, tal ora com . o caualuijr aa menagem que fezera, que, tal gasse, que sse verria a su[a] priiom. Et ora com. o caualgasse en besta, que el rrey dõ Fernando soltoo. Et el fezosse ueria a sua priiom. Et por esta razõ lle tal menage . et foysse a seu rreyno, sempre andou en andas et en colo dos et mandoullj entregar o que llj tomara omes ata que morreu. (Trad.Gall: en Galiza. Et el punou de guareçer, 691)

quanto mays pode; et, desque foy são, nũca ia mays quiso caualgar en besta por nõ vijr aa menagem que fezera, que tal ora com o caualgasse en besta, que sse verria a sua priiom del rrey. Et daly adeante sempre andou en andas en colos de omes ata que finou. (Trad.Gall: 721-722)

A Traduccion Gallega acrescenta um novo dado ao afirmar que Afonso Henriques não volta a montar para não ter que cumprir o juramento que fizera, «enganando» assim Fernando II, uma vez que se explica que se tratou de uma promessa equivoca. Este simples pormenor altera completamente o tom do episódio. Instaura a dúvida, no que respeita à pretensa piedade de Fernando II, e reverte a postura de submissão de Afonso Henriques que, nesta versão, se limita

\footnotetext{
Fernando enpos elles ferindo et matando. Et tã rrigeos entrarom pela porta da villa que quebrou a perna al rrey de Portugal, en . o ferrollo da porta da vila. Et os del rrey dom Fernando entrarõ ala cõ elles de volta, et foy preso el rrey de Portugal. Et troixerõno preso ante el rrey dõ Fernando. Et el rreçebeuo muy bem, et asentoo çerca de sy, et fezollj moyta onrra». (Trad.Gall: 721).
} 
a pedir perdão sem oferecer qualquer reparação exorbitante. Revela ainda esperteza e habilidade no manejo das palavras, usando-as de modo a obter e a manter a sua liberdade uma vez que, de acordo com este testemunho, não volta a montar, não por achaques da fractura, mas para não ter que cumprir a promessa feita.

E precisamente neste sentido que vai a segunda redacção da Crónica de 1344 , ao que acresce ainda a salvaguardada do valor do rei que, neste testemunho, parte a perna quando passa a porta, novamente no sentido que já vimos na Cr20R, não a fugir mas com a pressa de ir ajudar os seus, dada a sua valentia:

E, quando el rey dom Fernãdo chegou a Badalhouce, el rey dõ Affonso mandou armar toda sua companha e sayu fora da villa. E indo elle polla villa assy armado e . cima de seu cavallo, disseronlhe e. como ja suas gentes se embaratavam cõ dõ Diago e com dõ Fernã Roiz que tragiam a dianteira. E, quando esto ouvyo, ferio o cavallo das esporas tam rijamente por sayr da villa e chegar aos seus que era maravilha. Mas o que abrira a porta nõ colhera bem o ferrolho. E el rey levava o cavallo afficado das esporas, como aquelle que era o mais vallente e esforçado cavalleiro que se podia saber. Quãdo chegou aa porta, nõ se guardando daquelle ferrolho, topou o cavallo en elle de tam grande força que se britou a perna a el rey. E o cavallo steve pera cayr em terra, pero foy fora e chegou aos seus. Mas, des que começarõ a lidar, nõ o pode soffrer o cavallo, ca era chegado aa morte do grande golpe que dera no ferrolho, e leixousse cayr com elle. E cayulhe sobre aquella perna e britoulha toda. E os seus quyserõno levãtar e poer e . outro cavallo e non poderom, ca era a perna britada pela coixa. E entom chegou el rey dõ Fernando e prendeuoho e muytos dos seus cõ elle.

E, despois que el rey dõ Affonso foy preso e os seus vençidos, foisse el rey dõ Fernando pera a villa e levou cõsigo el rey dõ Affonso preso e fezelhe muy bem pensar da perna e fezlhe muyta honrra e preytejou cõ elle que lhe desse termho des o Minho ataa o castello de Lobeira que era seu e que lhe fezesse menage. que, tanto que cavalgasse e . besta, que tornasse a sua prisom. E elle fezeo assy como lhe foy demãdado, ca lhe nõ cõviinha de fazer outra cousa. E entom foy comprida a maldiçõ que lhe lançou sua madre quando lhe disse que ferros the quebrassem as pernas e preso fosse como ella era.

E el rey dom Fernando, despois que teve as fortalezas e recebeo delle a menagem, soltouo. E el rey dom Affonso tornousse pera sua terra e, despois, nunca cavalgou en besta por non aver razõ de tornar aa menagem. E sempre se des ally e. diante fez trager e. andas e e. collos d'home.s. E assy ãdou toda sua vida. (1344b: IV, 235-236)

A Crónica de 1344 já se vai diferenciar da Cr20R ao repetir a história, no reinado de Fernando II. No entanto, fá-lo nos termos que lhe são $\operatorname{caros}^{39}$. A

39 «E, logo que o soube, sacou sua hoste e foysse la. E el rey de Portugal quando soube que viinha, fez armar a sua gente e abrir as portas e sair a elles. E, quando elle foy armado e cavalgou en seu cavallo, disseronlhe que se elles embaratavam com dom Diago e com dom Fernam Rodriguez, ca estes eram entom vassallos del rey dom Fernando e tragiam a deanteira. E, quando el rey de Portugal aquello ouvyo, feriu o cavallo das esporas por chegar aos seus. Mas o porteiro que abrira a 
crónica portuguesa ainda coincide com a Cr20R ao atribuir o sucedido à concretização da maldição materna, um pormenor que só ocorre nas duas crónicas que veiculam, de modo mais desenvolvido, elementos das lendas épicas sobre a vida e feitos de Afonso Henriques. A maldição teria sido proferida por D. Teresa contra o seu filho quando este a derrotou e prendeu, anulando assim as aspirações desta ao governo do reino, mas, como se apressa a esclarecer Egas Moniz, o aio de Afonso Henriques, a Afonso VII:

E, quanto he por o fecto da rey . a sua madre, nõ o devees culpar, ca elle fez o que devya, ca ella o quisera matar ou desherdar da terra que seu padre gaanhou aos mouros e que el rey dom Affomso, vosso avoo e seu, lhe leixou. (1344b: IV, 219-220)

\section{EM JEITO DE CONCLUSÃO}

Face aos relatos que se concentram na promoção de uma única linha sucessória que ligaria, quase sem divisões ou problemas, os reis godos aos reis asturianos, leoneses e, finalmente, castelhanos, encontramos, no extremo ocidental da Península Ibérica, não só mais um ramo textual de uma extensa família cronística, mas também um ponto de vista alternativo sobre alguns passos da história peninsular, onde o reino mais recente, Portugal, tem o seu lugar e a sua justificação enquanto reino independente.

A narrativa historiográfica torna-se, assim, reflexo de algumas tensões e das relações políticas e de força que, de facto, existiam na Península. A enorme difusão desta família textual na Península Ibérica terá decorrido, em grande parte, da sua capacidade de adaptação à defesa de diferentes interesses. Consoante as necessidades sentidas em diferentes locais e épocas, o texto é actualizado cronologicamente e, ao mesmo tempo, é influenciado pelos diversos contextos que o rodeiam, o que leva à manipulação de conteúdos anteriores de forma a legitimar e a dar sentido a cada presente graças a cópias que nada têm de servil relativamente aos seus Modelos.

porta nom colhera bem o ferrolho e el rey, como levava o cavallo aficado das esporas, topou no ferrolho e britoulhe a perna pella coixa, pero por esto non leixou de chegar aos seus em um centenal. E alli se ajuntarom as aazes ferindosse fortemente. Mas o cavallo del rey de Portugal non o pode sosteer por que era mal ferido do golpe do ferrolho e outrossy das feridas que lhe deram na batalha, cayo morto em terra e cayolhe sobre aquella perna e britoulha ainda mais que era do ferrolho; e entom foy preso com peça dos seus que o queriam defender. E os outros fugirom pera a villa e os del rey dom Fernando entrarom com elles de volta pella porta e cobrarom a villa. E el rey de Leon foysse entom com el rey de Portugal pera a villa e fezlhe muyta honrra e fezlhe pensar da perna e preytejou com elle que lhe desse a terra que lhe tomara e que lhe fezesse menagem que, tanto que elle fosse guarido e que cavalgasse, que logo tornasse a sua prison. E elle fezlhe menagem ca lhe non conviinha al fazer. Mas depois nunca jamais cavalgou por non seer teudo aa menagem» (1344b: IV, 287-289). 
No caso da criação de um espaço na memória e no imaginário, para o reino português, nada melhor do que o uso da consagrada historiografia preexistente. Quer absorva textos produzidos no scriptorium do rei sábio, ou posteriores e ideologicamente marcados de modo diferente, trata-se de um corpus textual que remete para uma Autoridade. Assim, em Portugal fez-se o que já tinha sido feito anteriormente em Castela-Leão, aquando da reelaboração dos textos afonsinos: desvia-se, «modela-se» o Modelo, em consonância com novas ideias e ideais distintos mantendo, no entanto, a referência prestigiante à Auctoritas do rei Sábio.

Por conseguinte, a segunda redacção da Crónica de 1344 assume-se como cópia da Estoria de Espanna afonsina. E é-o, de facto, em grande medida. Mas, independentemente da recuperação da já consagrada historiografia afonsina, a segunda redacção da Crónica de 1344 prossegue e acentua o tom pró-português que já se verificava no texto de D. Pedro Afonso. Desta forma, a Auctoritas do prestigioso filão afonsino é aproveitada e integrada embora, simultaneamente, desviada. Assim, podemos dizer que a translatio a que a historiografia portuguesa procede cobre os diversos sentidos deste termo, uma vez que se verifica, não só um processo de tradução, como igualmente uma deslocação do acento ideológico ${ }^{40}$. Com efeito, esta segunda redacção do texto português, mais do que tradução, ou que transcrição, é, igualmente, interpretação, comentário, diálogo e, sobretudo, recriação do corpus afonsino.

40 Sobre o papel que a inventio pode ter no processo de tradução, ver CoPELAND, R., Rhetoric, Hermeneutics, and Translation in the Middle Ages, Cambridge, Cambridge University Press, 1991. 